\title{
Collection and Morphological Characterization of Local Okra (Abelmoschus esculentus L.) Genotypes in Northern Cyprus
}

\author{
Nihat Yılmaz ${ }^{1, a, *}$, Turgut Alas ${ }^{2, b}$, Handan Şapcı Selamoğlü, ${ }^{3, c}$ Zeynep Arı ${ }^{3 d}$, Hatice Bekci ${ }^{3, e}$ \\ ${ }^{1}$ Department of Crop and Animal Production, Safiye Çıkrıçıı̆lu Vocational College, Kayseri University, 38280 Kayseri, Turkey \\ ${ }^{2}$ Horticulture Production and Marketing Department, Faculty of Agricultural Sciences and Technologies, European University of Lefke, Northern Cyprus \\ ${ }^{3}$ Yahyall Vocational College, Kayseri University, 38280 Kayseri, Turkey \\ *Corresponding author
}

A R T I C L I N F O A B S T R A C T

Research Article

This study was conducted to collect local Okra (Abelmoschus esculentus L.) genotypes belonging to Malvaceae (Mallow) family in the Northern Cyprus and morphological characterization of this collected material. On the other hand, due to the limited studies on collection and morphological characterization, which are the first step of breeding; the genetic potential of the local okra genotypes of Northern Cyprus has not been determined before. This research was carried out in two

Received : 17/09/2020

Accepted : 08/07/2021 stages as the collection and morphological characterization of genotypes. In the first stage of the study, it was aimed to collect local okra genotypes and a total of 58 different locations were reached in line with this target and 24 samples of okra genotypes were collected from these areas. In the second year of the study, morphological characterization studies of 24 okra genotypes from the collected genetic material were carried out according to UPOV and IPGR criteria. As a result of

Keywords:

Genetic diversity

Plant genetic resources

Local accessions

Abelmoschus esculentus

Northern Cyprus morphological characterization showed that 24 okra genotypes can be categorized under 6 differen groups. The regenerated seeds of these 6 different genotypes were preserved. In conclusion, although morphological characterization analyses performed in this study are the methods used to differentiate new species from each other, but it will be insufficient alone. Therefore, it is concluded that this method will be used in coordination with molecular characterization studies to provide more reliable results.

\section{Introduction}

Okra (Abelmoschus esculantus (L.) Moench) is a member of the mallow (Malvaceae) family and is a type of plant that is grown for one year in temperate climates and perennial in tropical climates. Okra's origin is in India and Africa and it is produced commercially in Turkey, Asia, Iran, Greece, and Brazil (Düzyaman and Vural, 2002; Örkcü, 2016). The fruit of okra, whose leaves resemble grape leaves, has 5 parts, rounded seeds, greenish-gray and it is edible. (Elmac1, 2010).

In addition to using okra as a fresh vegetable, it is also used as frozen, dried, and canned. It can be used as coffee; oil produced from seeds is used in the perfume industry; and fiber, which is produced from fruits and roots, is used in the paper industry. Okra has nutritional value for the human diet and health. It is very rich in vitamin $\mathrm{A}, \mathrm{B}$, and $\mathrm{C}$, and nutrient minerals $\mathrm{Ca}, \mathrm{P}, \mathrm{Mg}$, and Fe content. Also, its iodine content is beneficial for goiter treatment in human health. The mucilage and fiber content in okra is important for diabetics as it helps to lower glucose (Omonhinmin and Osawaru, 2005; Samim et al., 2018).

For the rational use of plant genetic resources, information about the characterization and quantity of genetic diversity, and information on genetic diversity within closely related plant varieties is essential. In particular, the conservation of genetic resources is important in the current or future agricultural needs of these local varieties, which contain much genetic information and are in threatening of being lost, and because it is necessary to protect their genetic heritage. Morphological descriptors are the basis for the characterization of plant genotypes based on their appearance. The diversity based on phenotypic and morphological characters often varies with the environment, and evaluation of the features requires plants to reach full maturity before identification. There is a wide 
range of morphological variations, especially in the West African species, among Okra participation. Characterization and evaluation of crops are made to give information about the variety of crops (Saifullah and Rabbani, 2009; Pradip et al., 2010; Binalfew and Alemu, 2016; Samim et al., 2018).

In this study, morphological characterization of some local okra genotypes collected from Northern Cyprus was performed. Thus, it was aimed to preserve local genetic resources and to be a road map for genotypes for future breeding.

\section{Material and Methods}

\section{Plant Material}

This research was carried out in two stages as collection and characterization. In the first stage of the study, local okra genotypes were collected from different regions including 6 major regions (Nicosia, Morphou, Kyrenia, Famagusta, Trikomo and Lefka) of the Northern Cyprus, and in the second stage, morphological characterization studies were performed on the collected genetic material by using the UPOV descriptor. The material collection area of the research covered all villages and towns of Northern Cyprus, where these local okra genotypes were grown.

\section{Morphological Characterization of Genetic Material}

The morphological characteristics of the collected genetic material for the local okra genotypes were determined according to the criteria of the Protection of
New Varieties of Plants (UPOV) and Institute of Plant Genetic Resources (IPGR) using the 26 traits in Table 1.

The seeds of the collected samples were packed, labeled, and stored at $+2{ }^{\circ} \mathrm{C}$ in cold storage after cleaning. Morphological characterization studies were carried out on these collected okra genotypes. Sample identification and morphological characterization studies of the okra genotypes examined in the study were carried out on 26 traits (Table 1) that are suitable for observations in plants, leaves, and flowers and fruit observations according to UPOV and IPGR criteria.

\section{Data Analysis}

Statistical analysis of morphological characterization data was carried out using NTSYSpc computer programs (Rohlf, 1998). The genetic similarity between genotypes was determined using the cluster analysis SAHN in UPGMA (Unweighted Pair-Group Method Algorithm) within the NTSYS-pc program.

\section{Results and Discussion}

At the stage of collecting the seeds of local vegetable genotypes of the research, villages and towns were visited and the cultivated local okra genotypes were collected. During the trips in this study, a total of 58 locations were reached and a total of 24 samples were collected from these areas. The locations, where the materials were collected in this study and the names of the genotypes were given in Table 2 .

Table 1. Evaluated characteristics of okra samples

\begin{tabular}{l|c}
\multicolumn{1}{c|}{ Traits } & Traits \\
\hline Plant degree of branching & Flower size \\
Plant height & Fruit color \\
Stem diameter & Fruit intensity of color \\
Stem color & Fruit diameter of young fruit (at mid length) \\
Stem intensity of color & Fruit surface between ridges \\
Stem number of nodes (up to and including the first flowering node) & Fruit constriction of basal part \\
Leaf blade size & Fruit shape of apex \\
Leaf blade depth of lobing & Fruit number of locules \\
Leaf blade dentation of margin & Fruit thickness of carpel \\
Leaf blade color between veins & Fruit length of mature_fruit \\
Leaf blade intensity of color between veins & Fruit diameter of mature_fruit \\
Petiole length & Time of flowering \\
Petiole diameter & Time of commercial harvest \\
\hline
\end{tabular}

Table 2. Okra accessions used in the study and their geographic origin

\begin{tabular}{l|ccc}
\hline Accession no & Geographic origin & Accession no & Geographic origin \\
\hline Bam-01 & Lefke/Lefka & Bam-13 & Türkmenköy/Famagusta \\
Bam-02 & Doğanc1/Morphou & Bam-14 & Beyarmudu/Famagusta \\
Bam-03 & Yedidalga/Lefka & Bam-15 & Vadili/Famagusta \\
Bam-04 & Lapta/Kyrenia & Bam-16 & Vadili/Famagusta \\
Bam-05 & Akınc1lar/Nicosia & Bam-17 & Vadili/Famagusta \\
Bam-06 & Kuzucuk/Trikomo & Bam-18 & Ergazi/Famagusta \\
Bam-07 & Akdoğan/Famagusta & Bam-19 & Lapta/Kyrenia \\
Bam-08 & Bostanc1/Morphou & Bam-20 & Çayırova/Trikomo \\
Bam-09 & Bostanc1/Morphou & Bam-21 & Yeni Boğaziçi/Famagusta \\
Bam-10 & Doğanc1/Lefka & Bam-22 & Kumyalı/Trikomo \\
Bam-11 & Beyarmudu/Famagusta & Bam-23 & Büyükkonuk/Trikomo \\
Bam-12 & Beyarmudu/Famagusta & Bam-24 & Çinarli/Famagusta \\
\hline
\end{tabular}




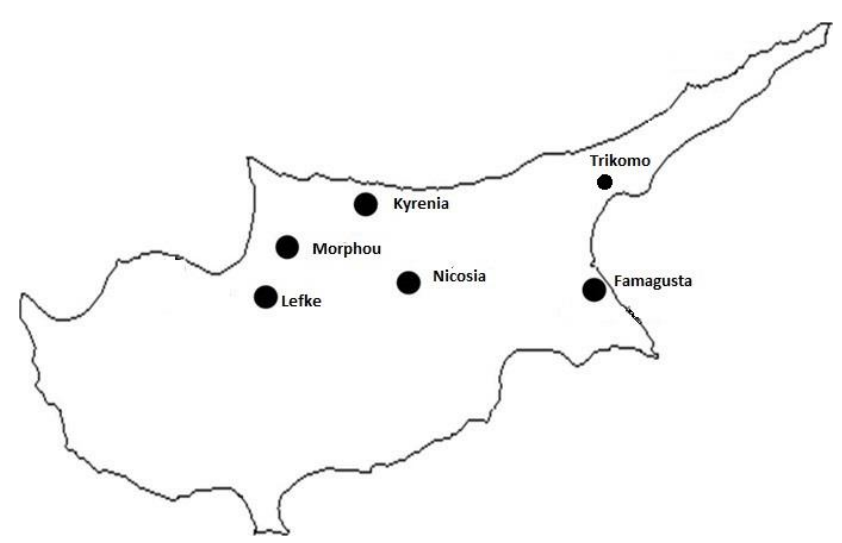

Figure 1. Collected 24 okra accessions in the study area and their geographic origin in Northern Cyprus

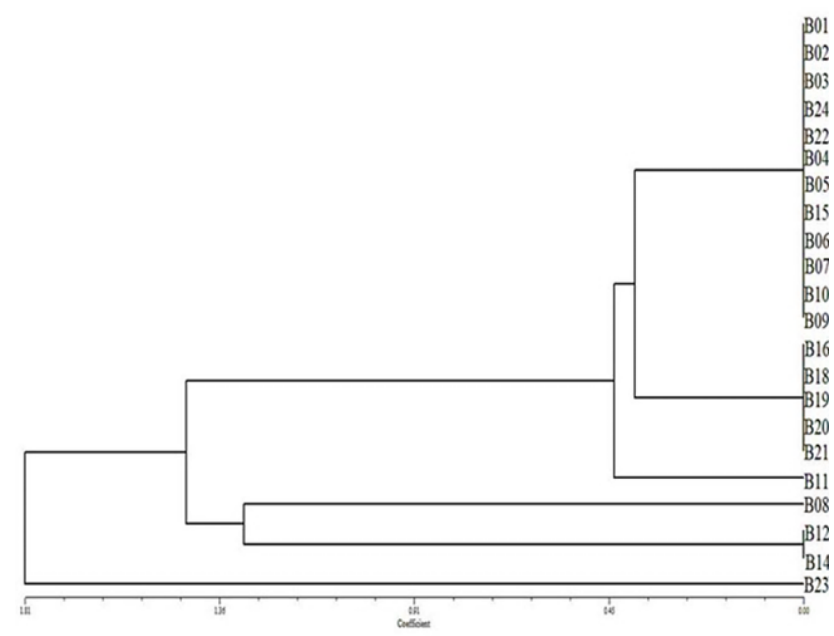

Figure 2. Dendrogram obtained by using 26 morphological traits (B: Okra)

24 local okra accessions were collected from different villages and towns belonging to Nicosia, Famagusta, Kyrenia, Trikomo, Morphou and Lefke districts of Northern Cyprus (Figure 1). In the visited villages, during the material collection, contacts were made with professional farmers, amateur vegetable producers as well as vegetable traders, sellers in vegetable markets and consumers in Northern Cyprus.

When the findings obtained from the research were evaluated in general, it was seen that okra genotypes could be distinguished from each other as a result of characterization studies based on morphological features. A total of 24 okra materials were collected in this study. No germination occurred in 2 samples "Bam-13 and Bam17 ', and the remaining 22 materials were germinated normally. Morphological studies are subjective evaluations, it may cause some lapses. However, the last products, which harvested at the end of the season, may give more objective evaluation and results. Genotype Bam16, which was thin, smooth, and longest in pod length, was formed a single group. In contrast, genotypes with the shortest pod structure Bam-03, Bam-07, Bam-08, and Bam-24 have been found as duplications and Bam-24 was selected for conservation and storage.

In addition, the genotype Bam- 05 was classified as thin and long, but it was kept separate and preserved due to the presence of deep grooves on the pod. In this study, it has been determined that there were differences in terms of other features, and the genotypes from there were also separated. Duplication occurred between the genotypes Bam-01, Bam-02, Bam-04, Bam-09, Bam-10, and Bam22. Bam-01 was separated from this group and taken under protection.

Another group of Bam-06, Bam-11, Bam-12, Bam-14, Bam-15, and Bam-23 genotypes were found to be duplicated. Bam-06 was stored for conservation.

Also, another genotype group determined to be duplication has concluded that all features were similar in Bam-18, Bam-19, Bam-20, and Bam-21 genotypes.

Thus, 6 different genotypes were found among 22 genotypes examined. Refreshed seeds of these six different genotypes were preserved.

In 22 okra genotypes, a dendrogram was obtained using 26 morphological features and the similarity between okra genotypes ranged between 0.84-1.00. Okra genotypes were divided into two main groups. While the B23 (Bam-23) genotype, which was one of the okra genotypes studied in the first main group, was formed as a separate group alone, other genotypes formed a second main group. The second main group was again divided into two subgroups. Among these groups, Bam-16, Bam-18, Bam-19, Bam-20 and Bam-21 genotypes formed a group together, while Bam01, Bam-02, Bam-03, Bam-04, Bam-05 Bam-06, Bam-07, Bam-09, Bam-10, Bam-15, Bam-22 and Bam-24 formed another group. On the other hand, the second subgroup formed two groups among themselves. In the first of these, Bam-12 and Bam-14 genotypes coexist, while B-08 (Bam08) genotype was grouped alone (Figure 2).

Within the scope of this research conducted in Northern Cyprus, which was a pioneering study not only for vegetables but for all plant species, were scanned and okra genotypes were collected and morphological characterizations were performed. On the other hand, the collection and morphological evaluation of okra genetic resources are among the research topics in many parts of the world. When the literature review was examined, some morphological characterization studies related to okra genotypes are encountered. Aladele et al. (2008), examined 93 okra genotypes from West Africa within the scope of their studies and observed that two different groups formed from these genotypes within the framework of the markers they used (Rohlf, 1998). On the other hand, Ariyo (1993) studied the morphological and agronomic character analysis of 30 genotypes from West Africa and concluded that there are six different groups among the genotypes (Aladele et al., 2008). In another study, Kumar et al. (2015) determined 8 different genotypes as a result of their studies on 30 okra genotypes six genotypes were found among the 22 genotypes evaluated in this study. Mohammed (2020) evaluated those thirty-one accessions of okra collected from farmers' field and two (LD-88 and Nhae-47) collected from the department of crop production, Federal University of Technology Minna in Nigeria and reported that accessions had variability and clustered in a different group.

It is possible to summarize the results obtained as a result of this study as follows;

- $\quad$ To keep the genetic diversity formed by the okra populations grown throughout Northern Cyprus, and to eliminate the type complexity, all of this material collected has been examined, morphological 
differences have been determined, the material that appears to be duplication has been separated and simplified, the fresh seeds of the rest have been produced and the basis of a national pod gene bank has been created.

- When all these results are evaluated in general, morphological characterization studies of the obtained material are the method used for differentiation of species, but their reliability is uncertain since some of the observations and measurements are sensory.

Therefore, as a matter of the fact that there was no previous morphological characterization study in Northern Cyprus has increased the importance of this study and at the same time, morphological characterization studies are considered to be insufficient alone. It was concluded that it would be beneficial to carry out in coordination with molecular characterization studies to give safer results in such studies.

\section{Acknowledgments}

This study was financially supported by The Scientific and Technological Research Council of Turkey (TUBITAK). Project number: 110-O-117.

\section{Conflicts of Interest}

The authors declare no conflict of interest

\section{References}

Aladele SE, Ariyo OJ, Lapena R. 2008. Genetic relationships among west African okra (Abelmoschus caillei) and Asian genotypes (Abelmoschus esculentus) using RAPD. African Journal of Biotechnology, 7: 1426-1431.

Ariyo OJ. 1993. Genetic diversity in West African okra (Abelmoschus caillei) (A. Chev.) stevels-multivariate analysis of morphological and agronomic characteristics. Genetic Resources and Crop Evolution, 40: 25-32.
Binalfew T, Alemu Y. 2016. Characterization of Okra (Abelmoschus esculantus (L.) Moench) germplasms collected from Western Ethiopia. International Journal of Research in Agriculture and Forestry, 3: 11-17.

Düzyaman E, Vural H. 2002. A Research on morphological variability of okra genotypes of different ecogeographic origins (Farklı ekocoğrafik kökenli bamya genotiplerinin morfolojik varyabilitesi üzerinde bir araştırma). Journal of Agriculture Faculty of Ege University, 39: 17-24.

Elmac1 S. 2010. Geographical Principles of Okra Agriculture in Amasya: Properties, Distribution and Problems Related to Production. Eastern Geography Review (Doğu Coğrafya Dergisi), 15: 117-130.

Kumar A, Verma RB, Solankey SS, Anupam A. 2015. Evaluation of okra (Abelmoschus esculentus) genotypes for yield and yellow vein mosaic disease. Indian Phytopathology, 68: 201206.

Mohammed AK, Oladiran JA, Gana AS, Bashir M. 2020. Variability studies among some okra (Abelmoschus esculentus L.Moench.) accessions from Niger State, Nigeria. International Journal of Food Science and Agriculture, 4: 143-147. DOI: https://doi.org/10.26855/ijfsa.2020.06.00

Omonhinmin C, Osawaru M. 2005. Morphological characterization of two species of Abelmoschus: Abelmoschus esculentus and Abelmoschus caillei. Plant Genet ResourNewsl (IPGRI/FAO), 144: 51-55.

Örkcü P. 2016. Morphological and Cytological Characterization of Okra Genotypes Provided from Different Locations. MSc Thesis, Institute of Natural and Applied Sciences, Namık Kemal University, Tekirdağ, Turkey.

Pradip AK, De DK, Pal AK. 2010. Genetic variability and diversity in Okra (Abelmoschus esculentus L. Moench). Electronic Journal of Plant Breeding, 1: 393-398.

Rohlf FJ. 1998. State University of New York, Stony Brook, New York.

Saifullah M, Rabbani G. 2009. Evaluation and characterization of Okra (Abelmoschus esculentus L. Moench.) genotypes. SAARC Journal of Agriculture, 7: 92-99.

Samim S, Sood S, Singh A, Verma A, Kaur A. 2018. Morphological characterization of Okra (Abelmoschus esculentus (L.) Moench). International Journal of Current Microbiology and Applied Sciences, 7: 2011-2019. 